\title{
Assessment of Technological Path of Hydrogen Energy Industry Development: A Review
}

\author{
N. Norouzi* \\ Department of Energy Engineering and Physics, Amirkabir University of Technology (Tehran Polytechnic), Tehran, Iran
}

\section{$P A P E R I N F O$}

\section{Paper history:}

Received 19 May 2021

Accepted in revised form 17 August 2021

\section{Keywords}

Hydrogen energy

Hydrogen industry

Renewable energy

Solid polymer electrolyte

\section{$A B S T R A C T$}

Hydrogen energy has the advantages of low carbon and cleanliness, high energy density, and high conversion efficiency; it is expected to play a pivotal role in Eastern Asia and the MENA region's energy transition. The research status and development prospects of various technologies in hydrogen production, hydrogen storage, and hydrogen use are analyzed. On this basis, specific technical paths for developing renewable energy and integrated energy service parks coupled with hydrogen energy are proposed. Solid polymer electrolyte (SPE) electrolysis hydrogen production and solid material hydrogen storage are the most potential development in directions of hydrogen production and hydrogen storage. Technologies such as hydrogen fuel cell and natural gas hydrogen mixture in the hydrogen use link should be simultaneously promoted. The organic combination of wind/light-abandoned hydrogen production by electrolysis of water, wind power/photovoltaic off-grid hydrogen production with fuel cell power generation, hydrogen refueling station supply, methanol production, and natural gas hydrogen mixing technology would effectively solve the uneconomical and transportation difficulties of renewable energy hydrogen production. At the same time, hydrogen energy can realize the interconnection of multiple energy networks, and its application prospects in the future integrated energy service parks are very broad.

doi: $10.5829 /$ ijee.2021.12.04.01

\section{INTRODUCTION}

The massive use of fossil energy has brought about various environmental, ecological, and global climate changes [1]. It became the conscious action of all countries to solve the dilemma actively and accelerated the development of energy transition, and the development of clean and low-carbon energy; which has a general trend [2]. Hydrogen energy is a recognized clean energy carrier with zero emis sions and pollution can be achieved in the whole process from development to utilization [3]. At the same time, hydrogen energy has the characteristics of high energy density and high conversion efficiency and is regarded as one of the most promising energy sources [4]. The International Hydrogen Energy Commission predicts that in 2050, hydrogen energy demand will reach ten times the current level, accounting for more than $15 \%$ of world whole energy consumption [5].
Some developed countries have incorporated the development of the hydrogen energy industry into their national development strategies [6]. The United States is an advocate of the hydrogen energy economy and one of the most important countries to promote the development of hydrogen energy [7]. In November 2002, the US Department of Energy promulgated the "National Hydrogen Energy Roadmap," which comprehensively and systematically explained hydrogen energy technologies such as hydrogen preparation, storage, transportation, conversion, and application [8]. So far, the US government has promulgated a series of policies and launched large-scale scientific research programs to actively guide and strive to realize the gradual transition from the fossil energy economy to hydrogen energy economy [9]. Germany is at the forefront of Europe in the promotion and application of hydrogen energy [5]. In 2011, German energy companies such as Greenpeace Energy established a 6MW wind-hydrogen

*Corresponding Author Email: nima1376@aut.ac.ir (N. Norouzi)

Please cite this article as: N. Norouzi, 2021. Assessment of Technological Path of Hydrogen Energy Industry Development: A Review, Iranian (Iranica) Journal of Energy and Environment, 12(4), pp. 273-284. Doi: 10.5829/ijee.2021.12.04.01 
demonstration project in Germany [4]. In addition, Audi built a $6 \mathrm{MW}$ photovoltaic-hydrogen-methane project (EGas project) in Germany in 2013 [5]. Hydrogen is produced through photovoltaic power generation and then reformed with carbon dioxide to produce methane. The annual methane production capacity reaches 1,000 tons. Japan is also at the forefront of hydrogen energy development and utilization [5, 6]. In 2014, the "Strategic Roadmap for Hydrogen Energy and Fuel Cells" was released, clarifying the three-phase development goals for 2025, 2030, and 2040 [8]. In 2017, Japan issued the "Hydrogen Energy Basic Strategy," which put forward specific development goals in hydrogen energy supply and utilization and planned to fully popularize fuel cell vehicles by $2050[9,10]$.

The Middle East, one of the world's largest oil exporters, is determined to become the world's largest exporter of green hydrogen, one of the world's largest carriers of green energy [3]. As governments and international oil companies move toward hydrogen fuel production; especially the green type, which comes from the electrolys is of water using solar or wind energy, major oil producers in their own Persian Gulf region have joined the global movement. Hydrogen is expected to play a key role in reducing global greenhouse gas emissions in the future, and the Middle East is reluctant to miss this emerging opportunity. On the other hand, given the accelerating transition to clean energy, Middle East wants to show the world that it is not just an exporter of crude oil but can also export clean energy. In addition, some Middle Eastern countries, whose economies are heavily dependent on oil, intend to diversify their economies and distance themselves from oil by moving towards clean energy production [11].

Recently, the world's media reported on two major green hydrogen production projects in Middle East; Dubai launched the first industrial-scale green hydrogen production project in the Middle East, and Oman unveiled plans to build one of the world's largest hydrogen production complexes. Dubai, one of the emirates of the United Arab Emirates, OPEC's third-largest oil producer, has partnered with the German company Siemens to launch the first industrial-scale green hydrogen production complex in the Middle East and North Africa region. Dubai Electricity and Water Company and Dubai Expo 2020 also contributed to this huge project [12].

According to experts at Siemens Energy, the large industrial complex uses electricity generated by the Mohammed bin Rashid Al Maktoum Solar Park during the day to generate green hydrogen through electrolysis. At night, the green hydrogen produced in this complex is converted into electricity and provides the electricity sustainably needed by Dubai [9]. The production capacity of this solar park is expected to reach 5 GW by 2030, which will be the highest production capacity of a solar park in the world. Companies in the region, their international partners and analysts, believe that Dubai and the entire Middle East region have a bright future in the field of solar energy, due to the region's climate [3]. "Despite the low cost of solar and wind energy production in the Middle East, the possibility of exporting this type of energy is limited," said Siemens Energy experts. "But hydrogen has the potential to play a key role in the world's energy portfolio in the future, opening up new export opportunities for regions that have favorable conditions for renewable energy production" [13].

In an interview with CNBC, Christine Bruce, CEO of Siemens Energy, said that the UAE could become a major exporter of hydrogen in the world. He mentioned, "I firmly believe that this business model can and should be one of the key business models in the UAE and the Middle East as a whole in the future and that the region will become an exporter of clean energy" [11].

Oman, another oil producer in the Middle East that is not a member of OPEC but is part of the OPEC Plus coalition, also is sued an important statement last week on clean energy production [1]. The Oman National Oil Company (OQ) has entered green hydrogen production in partnership with Hong Kong Intercontinental Energy Company and a Kuwaiti government-affiliated company that invests in and develops clean energy [3].

"Given the strategic location of the project, which is located between Asia and Europe, and the excellent conditions of the Arabian Sea in terms of abundant wind energy and solar radiation, this is a reliable project for production and supply," said the executives of Intercontinental Energy. "Permanent green fuels are very competitively priced worldwide" [4].

"Alternative energy is a key driver for Oman National Oil Company's long-term growth and a key component of the company's strategy," said Dr. Salim al-Hudhaili, director of alternative energy at Oman National Oil Company. "In addition, alternative energy is in line with Oman's 2040 vision, which aims to diversify the country's resources and maximize added value" [9].

The Middle East, the world's largest oil producer, and the world's largest oil exporter, also has a glimpse of green hydrogen production projects and gaining market share of this clean fuel [5]. Saudi Arabia's Crown Prince Mohammed bin Salman, widely publicized for a sustainable future, signed a $\$ 5$ billion deal last year with Saudi energy and freshwater Aqua power company Aqua Power. Under the agreement, a massive green hydrogenbased ammonia production complex will be built in the city of Neom, and its products will be exported to global markets [10].

As an important part of the country's strategic emerging industries, Eastern Asia and the MENA region will accelerate hydrogen energy development and industrial application [1]. Hydrogen energy has been included in the "Energy Technology Revolution, and Innovation Action Plan" and other major plan has been included in the State Council's "Government Work Report" [13]. At present, Eastern Asia and the MENA 
region's hydrogen energy research and development are still in the preliminary stage. There are still many problems to be resolved in various links in the hydrogen energy industry chain [9]. For example, the electrolyzer in the hydrogen production link, the vehicle-mounted hydrogen tank in the hydrogen storage link, the hydrogen compressor and the hydrogen refueling machine in the hydrogen refueling station link, the surface treatment of the bipolar plate in the fuel cell link, and the membrane electrode spraying equipment are all different in different countries [7]. In addition, the development path of hydrogen energy suitable for Eastern Asia and the MENA region's energy situation remains to be explored. From the perspective of Eastern Asia and the MENA region's energy structure and transformation trends, the development of wind power, photovoltaics, and other renewable energy sources is very rapid and will play an increasingly important role [9]. The coupled development of renewable energy and hydrogen energy will become an important direction [11]. In addition, integrated energy services have become a hot spot in the energy and power industry. Compared with traditional energy services, integrated energy services pay more attention to clean and low-carbon energy use and improve users' energy efficiency [12]. Hydrogen energy has the natural properties of being clean and low-carbon, and at the same time, it can realize the interconnection of multiple types of energy networks such as power grids and heating networks, gas networks, and transportation networks [14]. The application prospects of integrated energy service parks in the future are very broad [15].

This article first analyzes the research status and development prospects of various technologies in the fields of hydrogen production, hydrogen storage, and hydrogen use, and on this basis, proposes a hydrogen energy development technology path suitable for different regional conditions to provide a reference for the development of the hydrogen energy industry. This paper aims to overview the current situation of the hydrogen industry and its potential growth opportunities to know the advantages and disadvantages of the hydrogen industry. Then, to suggest diverse strategies to help this industry grow in different regions aligned to the MENA and Eastern Asian regions.

\section{RESEARCH ON KEY TECHNOLOGIES OF THE HYDROGEN ENERGY INDUSTRY CHAIN}

There are many hydrogen preparation methods, and the common industrial hydrogen production methods mainly include the following categories.

\section{Hydrogen production from fossil fuels}

It mainly includes hydrogen production by steam reforming petroleum and natural gas and using the water gas method [8]. Hydrogen production from fossil fuels is a low-cost hydrogen production method. The cost of hydrogen production can be controlled at $0.6-1.5 \mathrm{yuan} / \mathrm{m}^{3}$ $[9,10]$. At present, more than $95 \%$ of hydrogen in Eastern Asia and the MENA region is produced from fossil fuels such as coal, natural gas, and petroleum [13]. Fossil fuels produce a large number of carbon emissions in the process of hydrogen production. Therefore, carbon capture and storage (CCS) technology must be combined to be more widely recognized and applied in the future.

\section{Hydrogen production from industrial by-products}

It mainly includes the recovery of hydrogen-rich system hydrogen in refineries, the recovery of by-product hydrogen in Chlor-alkali plants to produce hydrogen, and the recovery and utilization of hydrogen in coke oven gas [11] These technologies make full use of industrial byproducts, the process is mature, and the cost of hydrogen production is low, with 1.3 to $1.5 \mathrm{yuan} / \mathrm{m}^{3}$ [9].

\section{Hydrogen production by electrolysis of water}

Hydrogen production by electrolys is of water is also one of the traditional hydrogen production methods, and the process is simple and pollution-free [12]. Since electricity costs account for about $70 \%$ of operating cos ts , the purely electrolyzed hydrogen production process is not economical. However, Eastern Asia and the MENA region are currently vigorously promoting the development of renewable energy. The surplus electricity generated during the process of abandoning wind and light has created favorable conditions for the development of hydrogen production by electrolysis of water. Hydrogen production by water electrolysis has become an important technical choice for peak-shaving, valley-filling, and abandonment of electricity in Eastern Asia and the MENA region's power industry [12].

Common water electrolysis hydrogen production technology is divided into alkaline water, a solid polymer electrolyte (solid polymer electrolyte, SPE), and solid oxide electrolyte (solid oxide electrolyzer cell, SOEC) electrolysis of water; three comparative techniques are summarozed in Table 1 [14-16]. Alkaline water electrolysis technology has been relatively mature; SPE water electrolysis technology has begun to be used commercially in different countries but is basically in Eastern Asia and MENA region's experimental research and development stage; SOEC electrolys is technology is currently in the research and development stage at home and abroad [14]. Compared with alkaline water electrolysis, SPE water electrolys is hydrogen production equipment has a wider operating power range and shorter start-up time; one can realize high current density electrolysis, low power consumption, small size, high purity of generated gas, and easy to achieve high pres sure, More suitable for the volatile input of renewable energy power generation. Therefore, SPE water electrolysis technology will be an important development direction for hydrogen production technology in the future [9]. 
Table 1. Comparison of water electroly sis technologies

\begin{tabular}{|c|c|c|c|}
\hline Compare items & Alkaline water electrolysis & SPEpure water electrolysis & Solid oxide electrolysis \\
\hline Electrolyte & $20 \% \sim 30 \% \mathrm{KOH}$ & SPE film & $\mathrm{Y}_{2} \mathrm{O}_{3} / \mathrm{ZrO}_{2}$ \\
\hline Working temperature $/{ }^{\circ} \mathrm{C}$ & $70 \sim 90$ & $70 \sim 80$ & $700 \sim 1000$ \\
\hline Current density $/\left(A \cdot \mathrm{cm}^{-2}\right)$ & $0.2 \sim 0.4$ & $1 \sim 2$ & $1 \sim 10$ \\
\hline Electrolysis efficiency $/ \%$ & $60 \sim 75$ & $70 \sim 90$ & $85 \sim 100$ \\
\hline $\begin{array}{l}\text { Energy consumption/[(kW.h). } \\
\left.\mathrm{m}^{-3}\right]\end{array}$ & $4.5 \sim 5.5$ & $3.8 \sim 5.0$ & $2.6 \sim 3.6$ \\
\hline Operating characterist ics & Start and stop faster & Start and stop fast & Inconvenient start and stop \\
\hline Dynamic response capability & Stronger & Strong & - \\
\hline Power quality requirements & Stable power supply & Stable or fluctuating & Stable power supply \\
\hline $\begin{array}{l}\text { System operation and } \\
\text { maintenance }\end{array}$ & $\begin{array}{c}\text { Corrosive liquid, complicated } \\
\text { operation and maintenance in later } \\
\text { stage, high cost }\end{array}$ & $\begin{array}{l}\text { Simple operation and } \\
\text { maintenance, low cost }\end{array}$ & $\begin{array}{l}\text { Currently focusing on technical research, } \\
\text { no operation, and maintenance } \\
\text { requirements yet }\end{array}$ \\
\hline Stack life/h & 120000 & 100000 & - \\
\hline Technology maturity & Commercialize & Commercialization abroad & Development phase \\
\hline Whether there is pollution & Lye pollution, asbestos carcinogenic & No pollution & No pollution \\
\hline
\end{tabular}

In addition, some new hydrogen production technologies have emerged in recent years, including photocatalytic hydrogen production, hydrogen production from nuclear heat, and hydrogen production from biomass [12]. However, these technologies are currently in the laboratory research stage, far away from industrial applications. Hydrogen storage technologies include pressure gas storage, cryogenic liquid hydrogen storage, hydrogen storage, and an organic solid material liquid hydrogen storage, see the comparative technical Table 2 [9] High-pressure gaseous hydrogen storage has the advantages of lower cost and mature technology and is more suitable for application in fuel cell vehicles. It will still be the main stream hydrogen storage technology in the next few years [13] Toyota Motor Corporation of Japan is at the forefront of hydrogen storage containers for high-pressure vehicles [1]. The fully-wound plastic liner gas cylinders (Type IV) developed by Japan can achieve $70 \mathrm{MPa}$ high-pressure sealed hydrogen storage, and the mass density of hydrogen storage reaches $5.7 \%$ (Mass score) [9]. Commercial hydrogen storage containers for high-pressure vehicles in Eastern Asia and the MENA region use forged aluminum alloy as the inner liner, and carbon fiber gas cylinders (Type III) are coated outside [15]. Hydrogen storage cylinders pressurized at $35 \mathrm{MPa}$ have been widely used in-vehicle systems, but 70 $\mathrm{MPa}$ high-pressure gas cylinders are not commercially available yet $[16,17]$. Low-temperature liquid hydrogen storage technology has the advantages of high hydrogen storage density and high hydrogen transmission efficiency, but the storage and transportation costs are relatively high [18]. Mainly reflected in: First, the liquefaction and compression of gaseous hydrogen require a large amount of energy, which is about $30 \%$ of the hydrogen itself, and the energy consumption is very high [9]; second, the liquid hydrogen storage container needs to be insulated and resistant to high pressure, and the production cost is high [15]. Liquid hydrogen storage has been commercially applied in developed countries like the United States and Japan [1, 2]. However, Eastern Asia and the MENA region's regulations on liquid hydrogen storage are relatively strict, mainly used in the aeros pace field, and civilian use is not allowed. The future development trend is difficult to predict [9].

Although the hydrogen storage technology of solid materials is still in the transitional stage from experimental research to commercial application. The cost of hydrogen storage is relatively high, its advantages, such as high volumetric hydrogen storage density and safe and convenient operation, will promote the development and promotion of the technology [15]. This technology will be used in hydrogen storage in the future. The fields with higher safety requirements have broad application space, an important future development direction of hydrogen storage technology [13]. The advantages and disadvantages of organic liquid hydrogen storage technology are obvious [9]. At present, commercial applications have been realized in Eastern Asia and the MENA region and will become an important supplement to hydrogen storage technology [13]. 
Table 2. Comparison of hy drogen storage technologies

\begin{tabular}{|c|c|c|c|c|}
\hline Compare items & $\begin{array}{l}\text { High-pressure gaseous } \\
\text { hydrogen storage }\end{array}$ & $\begin{array}{l}\text { Low-temperature liquid } \\
\text { hydrogen storage }\end{array}$ & $\begin{array}{c}\text { Hydrogen storage in solid } \\
\text { materials }\end{array}$ & Organicliquid hydrogen storage \\
\hline $\begin{array}{l}\text { Hydrogen } \\
\text { storage density } \\
\text { per unit mass } / \%\end{array}$ & $1.0 \sim 5.7$ & $5.7 \sim 10$ & $1.0 \sim 4.5$ & $5.0 \sim 7.2$ \\
\hline Technology & $\begin{array}{l}\text { Use high pressure to } \\
\text { compress hydrogen into a } \\
\text { high-pressure container for } \\
\text { storage }\end{array}$ & $\begin{array}{l}\text { The hydrogen is liquefied } \\
\text { under high pressure and low } \\
\text { temperature, and the volume } \\
\text { density is } 845 \text { times that of } \\
\text { gaseous state }\end{array}$ & $\begin{array}{l}\text { The hydrogen is stored in the } \\
\text { solid material by the solid's } \\
\text { physical adsorption or chemical } \\
\text { reaction on the hydrogen } \\
\text { without pressure and in a low- } \\
\text { temperature environment. }\end{array}$ & $\begin{array}{l}\text { The unsaturated organic liquid } \\
\text { undergoes a hydrogenation reaction } \\
\text { under a catalyst to generate a stable } \\
\text { compound and then undergoes a } \\
\text { dehydrogenation reaction when } \\
\text { hydrogen is required. }\end{array}$ \\
\hline Advantage & $\begin{array}{l}\text { Low cost, mature } \\
\text { technology, fast hydrogen } \\
\text { charging and discharging } \\
\text { rate, low energy } \\
\text { consumption, and wide } \\
\text { working conditions }\end{array}$ & $\begin{array}{l}\text { The volumetric hydrogen } \\
\text { storage density is high, the } \\
\text { liquid hydrogen purity is } \\
\text { high, and the hydrogen } \\
\text { transmission efficiency is } \\
\text { high }\end{array}$ & $\begin{array}{l}\text { The volumetric hydrogen } \\
\text { storage density is high, the } \\
\text { operation is safe and } \\
\text { convenient, no high-pressure } \\
\text { container is needed, and the } \\
\text { hydrogen purity is high }\end{array}$ & $\begin{array}{c}\text { The hydrogen storage density is high, } \\
\text { the cost is relatively low, and the } \\
\text { safety is high }\end{array}$ \\
\hline Disadvantage & $\begin{array}{l}\text { The volumetric hydrogen } \\
\text { storage density is low, the } \\
\text { volume-specific capacity is } \\
\text { small, and there is a potential } \\
\text { safety hazard of leakage or } \\
\text { explosion. }\end{array}$ & $\begin{array}{l}\text { The liquefaction process } \\
\text { consumes a lot of energy, is } \\
\text { volatile, and has a high cost }\end{array}$ & $\begin{array}{l}\text { The quality of hydrogen storage } \\
\text { has low density, high cost, } \\
\text { temperature requirements for } \\
\text { hydrogen absorption and } \\
\text { release, and poor resistance to } \\
\text { impurity gases }\end{array}$ & $\begin{array}{l}\text { The purity of hydrogen is not high, } \\
\text { side reactions may occur, and } \\
\text { impurity gases are generated; the cost } \\
\text { is high, hydrogenation and } \\
\text { dehydrogenation devices must be } \\
\text { equipped; the dehydrogenation } \\
\text { reaction is often carried out at high } \\
\text { temperatures catalyst is prone to } \\
\text { coking and deactivation. }\end{array}$ \\
\hline Application & $\begin{array}{l}\text { Currently, the most mature } \\
\text { and commonly used } \\
\text { technology, which is also the } \\
\text { main technology used for } \\
\text { hydrogen storage in vehicles }\end{array}$ & $\begin{array}{l}\text { Mainly used in the aerospace } \\
\text { field, suitable for ultra-high- } \\
\text { power commercial vehicles }\end{array}$ & $\begin{array}{l}\text { Important development } \\
\text { direction in the future }\end{array}$ & $\begin{array}{c}\text { Can use traditional petroleum } \\
\text { facilities for transportation and } \\
\text { bunkering }\end{array}$ \\
\hline
\end{tabular}

Hydrogen has multiple properties such as energy storage, fuel, and industrial raw materials, making it a broad application space in various industries [9]. The hydrogen energy utilization model can be abstracted into the following aspects [15].

\section{Power to power conversion}

Hydrogen production by electrolysis realizes the conversion of electric energy into hydrogen energy. If necessary, hydrogen energy can be converted into electric energy again through fuel cells [18]. This model can fully use renewable energy such as wind power and photovoltaics to generate hydrogen [13]. It is a form of energy storage and power generation with broad application prospects [19]. It can solve grid peak and valley filling, stable grid connection of new energy, improve power system security, reliability, flexibility, significantly reduce carbon emissions, promote smart grids, energy-saving emission reduction, and resource sustainable development strategies [20]. However, under this model, the price of hydrogen production is still high, and the safety of large-scale hydrogen storage and investment income are factors that restrict the promotion of this technology [21]. In the early stage, the state needs to formulate relevant power market regulations and policies to promote the promotion and application of this technology [22].

\section{Power to gas conversion}

After hydrogen is produced by electrolysis, the hydrogen is directly mixed into the natural gas pipeline or after synthesizing methane; the mixed natural gas is used as a fuel at the terminal to provide heat energy [23]. This model breaks the barriers between the traditional power system and the natural gas system and can expand the utilization and popularization of renewable energy [24]. Use wind power, photovoltaic power generation, and other surplus electricity to electrolyze water to generate hydrogen, and then provide it to the existing gas pipeline network, or use electricity, water, and carbon dioxide in the atmosphere to produce methane to provide fuel gas through the methanation reaction, thus promoting the "gas network" -The deep integration of the power grid [25-27].

\section{The conversion of electric energy to fuel (power to fuel)}

After hydrogen is produced by electrolysis, the hydrogen is stored in the form of a fuel cell [28]. Implementing fuel cell vehicle hydrogenation and a hydrogen fuel cell-based 
integrated thermoelectric system on the user side can promote grid peak reduction [29], Valley filling, realize the interconnection of multiple types of energy networks such as the grid and the heating network, gas network, and transportation network, and promote comprehensive energy efficiency utilization and "clean replacement" to increase the proportion of electricity in the final energy consumption, play a key role in the construction of a new generation of power systems and the construction of the global energy Internet [30]. Among them, hydrogen fuel cell vehicles are the pioneering direction of hydrogen energy development [31]. Compared with lithium-ion battery electric vehicles, hydrogen fuel cell vehicles have the advantages of high power density, long cruising range, and fast fuel refueling. The market for the future is ultra-high-power heavy-duty vehicles with a driving range of more than $800 \mathrm{~km}$ [32]. Long-distance vehicles, as well as commercial vehicles that can operate 24 hours to improve efficiency, etc [33].

\section{The conversion of electric energy to raw materials (power to feed)}

Hydrogen and its derivatives have become a key raw material in many industries, especially chemical production and refining [34]. In Eastern Asia and the MENA region, hydrogen is used as raw material gas for synthetic ammonia, methanol, and other chemical industries, and about $90 \%$ or more of hydrogen with a purity of about $99 \%$ is used for hydrogenation in the production of refining and chemical products [35]. In addition, 2 to $4 \%$ of hydrogen is used as an industrial gas for reducing gas, protective gas, and reaction gas in metallurgy, steel, electronics, building materials, fine chemicals, and other industries [36]. At present, the amount of hydrogen consumed in the industrial sector worldwide each year exceeds 50 billion cubic meters [37]. Approximately $70 \%$ of the world's hydrogen is used to synthesize ammonia, and the hydrogen consumption of Eastern Asia and the MENA region's synthetic ammonia is more than $80 \%$ [38]. Replacing carbon-based hydrogen with hydrogen from renewable energy will contribute to global carbon emissions reduction [39].

Hydrogen fuel cell vehicles are currently the most concerned hydrogen energy utilization in Eastern Asia and the MENA region. It is also the starting point for building a hydrogen energy society and increasing the public's acceptance of hydrogen energy [40]. However, the use of hydrogen energy in other fields should also be simultaneously carried out research and development, such as natural gas hydrogenation, clean replacement of hydrogen in the industrial field, etc, which has a significant impact on the development of the hydrogen energy industry and the acceleration of Eastern Asia and MENA region's low-carbon and clean process [41, 42].

\section{HYDROGEN ENERGY TECHNOLOGY PATH \\ DEVELOPMENT}

Because of the characteristics of Eastern Asia and the MENA region's energy structure and the trend of the energy transition, combined with the maturity of hydrogen energy industry technology development, this paper proposes two technical paths for the production and utilization of hydrogen energy [43].

Renewable energy such as wind power/photovoltaic power generation to produce hydrogen by electrolys is of water can reduce fossil energy consumption, reduce pollutant emissions, improve grid absorption capacity, and realize the polygeneration of wind power photovoltaics, coal chemical industry, and petrochemical industry (see Figure 1) [43-46]. Popular research directions in the development of the hydrogen energy industry [47]. Wind power/photovoltaic hydrogen production currently faces two major challenges: cost and transportation [48]. For cost problems, the following two techniques described herein recommended route.

\section{Abandoning wind/light to produce hydrogen by electrolyzing water}

The cost of hydrogen production by water electrolysis is much higher than that of coal gasification and natural gas cracking for hydrogen production [48]. The cost of electricity accounts for about $70 \%$ of the operating cost of hydrogen production by electrolys is [49]. If wind/light electricity is used to produce hydrogen, the cost of hydrogen production can be controlled at Around 1.5 yuan $/ \mathrm{m}^{3}$ (the negotiated price of abandoned wind/abandoned solar power is controlled within 0.2 yuan $/(\mathrm{kW} \cdot \mathrm{h})$ ) [50], which initially has the conditions to compete with fossil fuel hydrogen production. Although the average curtailment rate of wind power/photovoltaic power in Eastern Asia and the MENA region has shown a clear downward trend in recent years, the curtailment of

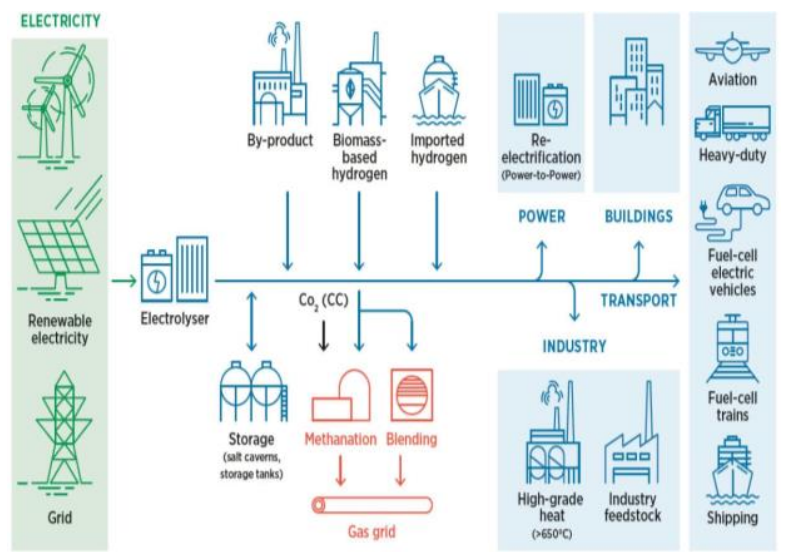

Figure 1. Development roadmap of renewable energy coupling hy drogen energy 
wind/light in Northwest Eastern Asia and the MENA region is still serious. In 2018, the curtailment rate in Xinjiang was as high as $23 \%$, and the curtailment rate in Gansu was 19\% [50]. In addition, the wind power/photovoltaic parity policy after 2020 has also stimulated the construction of a large number of wind power/photovoltaic projects [51]. The grid construction cannot keep up with wind power/photovoltaic power [52]. The difficulty of absorbing wind power/photovoltaic power generation in the future cannot be ignored. Therefore, abandoning wind/light to produce hydrogen from electrolyzed water is important to solve new energy consumption and efficient utilization [53].

\section{Wind power/photovoltaic off-grid hydrogen production}

In areas where wind/light resources are abundant but difficult to connect to the grid and cannot be developed on a large scale, such as the "Three North" areas that have long been in the red warning for new energy consumption, wind power/photovoltaic power generation can be used to produce hydrogen from the off-grid operation [54]. In this way, the cost of wind power/photovoltaic grid connection can be saved, and the large-scale hydrogen production of wind power/photovoltaic off-grid can reduce the equipment cost of hydrogen production plants [55]. Under this circumstance, the cost of hydrogen production can be controlled within two yuan $/ \mathrm{m}^{3}$, which has a broad application space in the future development of lowcarbon and clean development in Eastern Asia and the MENA region [56].

Another problem is applying water electrolysis technology to produce hydrogen from renewable energy sources such as wind power/photovoltaic is transportation and application issues. This article proposes four possible paths [57]:

\section{Fuel cell power generation}

Using gaseous hydrogen storage to temporarily buffer hydrogen and then use fuelcells for power generation can greatly improve the accuracy of wind/photoelectric tracking plans, realize the comprehensive optimal utilization of grid-hydrogen energy storage, and improve the quality of the power supply [57].

2. Supply hydrogen refueling station

When there is a hydrogen refueling station near the wind farm, the hydrogen can also be sold to the hydrogen refueling station to replenish nearby fuel cell vehicles [58].

3. Carbon dioxide hydrogenation to produce methanol When wind farms/photovoltaic power plants are located in remote areas that are not conducive to hydrogen transportation, consider building a carbon dioxide hydrogenation device near the wind farm to convert the dangerous hydrogen trans portation problem into safe and easy trans portation of carbon dioxide and methanol [59]. At the same time, it can reduce or maintain the concentration of carbon dioxide in the atmosphere and obtain methanol, an important energy carrier, a technical route that "kills two birds with one stone and turns was te into treasure" [60]. Currently, this technology has achieved commercial application in Iceland, and it is still in the exploratory period of commercial application in Eastern Asia and the MENA region. It will have good application prospects in remote areas of the northwest in the future [61].

4. Natural gas is mixed with hydrogen

For areas where hydrogen produced by wind power/photovoltaic power is not conducive to overseas transportation but is close to natural gas pipelines, the use of hydrogen-mixed natural gas transportation is a more promising direction [62]. The hydrogenation of natural gas can improve natural gas combustion efficiency, reduce pollutants and carbon emissions, and reduce Eastern Asia and the MENA region's natural gas imports and foreign dependence, which is of great significance to Eastern Asia and the MENA region's energy security strategy. Studies have shown that the proportion of natural gas mixed with hydrogen is controlled within $23 \%$, not affecting natural gas pipelines' structure and combustion performance [63, 64]. Natural gas hydrogenation technology has been widely used abroad, but it is still in the experimental research stage in Eastern Asia and the MENA region [65].

With the emergence of a new round of energy technology revolution and the accelerated penetration of the Internet concept into the energy sector, the reform of the energy system has continued to deepen [66]. Customer needs have become more diversified, building an integrated energy system and providing users with multiple energy production, storage, transmission, consumption, and energy [67]. Comprehensive energy services with deep integration of market transactions have become a hot spot in the energy and power industry [68]. Various industrial parks have natural resources, space resources, grid foundations, and use resources to construct an integrated energy system and become the main battlefield for integrated energy services, business innovation, and benefit growth [69]. Integrated energy services pay more attention to clean and low-carbon energy use compared with traditional energy services and improve users' energy efficiency. Hydrogen energy has the natural properties of being clean and low-carbon. It can also realize the interconnection of energy networks such as power grids and heating networks, gas networks, and transportation networks. The application prospects in integrated energy service parks in the future are very broad [70].

Integrated energy services development of hydrogen technology park coupling path as Figure 1 shows. The energy supply in the park is mainly completed by distributed wind power or photovoltaic power. Wind power or photovoltaic power generation that the grid cannot absorb is used for electrolysis hydrogen 
production [71]. The stored hydrogen can be directly supplied to the park or nearby hydrogen refueling stations to meet hydrogen fuel cell vehicles [72]. At the same time, a fuel cell system can be configured for combined heat and power. Especially high-temperature fuel cells, such as solid oxide fuel cells and molten carbonate fuel cells, have higher co-generation efficiency and betterfuel adaptability (processed natural gas or syngas can be used) [73]. At present, molten carbonate fuel cells have been in demonstration operation in the United States, Japan, Germany, Italy, South Korea, and other countries, and the power capacity has reached the megawatt level or more [74]. Japan has implemented the ENE-FARM plan, and the development and market application of household fuel cell combined heat and power systems have matured. In 2018, the shipment of stationary fuel cells exceeded $300 \mathrm{MW}$ [75].

Another technical path for the park's combined heat and power is the micro gas turbine combined heat and power technology that uses natural gas mixed with hydrogen as fuel [76]. Compared with conventional gas turbines fueled by natural gas, gas turbines fueled by natural gas mixed with hydrogen can significantly reduce nitrogen oxides and carbon dioxide emissions, which is the key direction of future green and low-carbon development [77]. The research results show that when the hydrogen blending amount is below $20 \%$, there is no need to make major modifications to the gas turbine. In March 2018, MitsubishiHitachi Power Systems Co., Ltd. conducted a gas turbine test using a $30 \%$ hydrogen fuel mixture [78]. The test results confirmed that stable combustion could be achieved using a newly developed proprietary burner to burn the hydrogen-natural gas mixture [79]. Compared with conventional natural gasfueled gas turbines, a 30\% hydrogen mixture can reduce carbon dioxide emissions by about $10 \%$ [80].

The world's largest oil exporter, the Middle East, is looking to become an exporter of clean green hydrogen energy [81]. Due to the growing interest of governments and international oil companies in clean energy, oil producers in Persian Gulf region have become interested in hydrogen, especially the green type, which is produced by electrolysis of water using electricity generated from solar or solar, or wind energy [82]. Hydrogen is expected to play a key role in reducing carbon emissions by the energy industry, and the Middle East does not want to mis s this opportunity [83]. On the one hand, as the energy transition accelerates, it wants to show the world that it can export crude oil and clean energy [84]. On the other hand, oil-based economies some of OPEC's largest producers are determined to diversify their activities, reduce their dependence on oil, and turn to clean energy exports. In 2019, the announcement of two green hydrogen projects in the Middle East made headlines, one was the launch of Dubai's first industrial green hydrogen project in the region, and the other was the unveiling of Oman plans to build one of the largest green hydrogen plants in the world [85]. In collaboration with Siemens Energy, the Dubai Electricity and Water Authority (DEW A), and Expo 2020 Dubai, Dubai has launched the first green hydrogen facility in the Middle East and North Africa region on an industrial scale powered by solar energy [86]. To generate green hydrogen through electrolysis, the plant uses solar power to generate solar energy during the Mohammed bin Rashid Al Maktoum solar park during the day. Green hydrogen is converted into electricity at night to power the city with sustainable energy [87]. The solar park is expected to generate a maximum of five gigawatts of clean energy by 2030 , making it the largest solar base in the world [88].

Companies in the region, international technology partners, and analysts believe that Dubai and the entire Middle East have a bright future in solar power generation due to its abundant sunlight. Given the low electricity costs for solar photovoltaics and wind power in the region, Siemens has the potential to become a key fuel in the future energy basket and could provide energy export opportunities for areas with abundant renewable energy [89]. "I believe that hydrogen should be and will be one of the key future business models in the UAE and the region as a whole and that the region will be the world's largest energy exporter in the future," Christine Bruch, Siemens Energy CEO, told CNBC [90]. Oman, a nonOPEC member, is another oil producer in the Middle East that announced an important green hydrogen program last week [91]. Oman State Energy Company OQ, Hong Kong Intercontinental Energy Company, and Kuwait Entertech have announced plans for one of the largest green hydrogen facilities in the world. The plant will operate on 25 gigawatts of renewable energy and cost up to $\$ 30$ billion [92]. Saudi Arabia, the Middle East's largest oil producer and the world's largest oil exporter is also looking at green hydrogen projects and its share of the emerging clean hydrogen market [93]. Last year, the carbon-free city of Neom signed a $\$ 5$ billion contract for a green hydrogen-based ammonia production project that will export the product. According to oil price, these programs show that Middle East oil giants are not immune to the energy transition and growing global demand for clean energy products [94].

\section{CONCLUSION}

This article introduces various technologies in the process of hydrogen production, hydrogen storage, and hydrogen use, summarizes the development status and scope of application of these technologies, and on this basis, proposes a hydrogen energy development path suitable for Eastern Asia and the MENA region's conditions. In the process of hydrogen production, hydrogen production by electrolysis of water has become an important technology choice for Eastern Asia and the MENA region's power industry to cut peaks, fill valleys, and 
abandon power consumption. Among them, SPE electrolysis of hydrogen production technology is more suitable for the fluctuating input of renewable energy power generation. SPE is an important development direction of electrolyzed water technology in the future. In the hydrogen storage link, high-pressure gaseous hydrogen storage will still be the mainstream hydrogen storage technology in the next few years. Still, solid-state hydrogen storage technology will become an important development direction for future hydrogen storage technology due to its high volumetric hydrogen storage density and safe and convenient operation. In the use of hydrogen, hydrogen fuel cells are an important starting point for building a hydrogen energy society and increasing the public's acceptance of hydrogen energy. However, for the development of the hydrogen energy industry and the acceleration of Eastern Asia and the MENA region's low-carbon and clean process, hydrogen energy is in other areas. The use of fields should also be paid attention.

Among the technological paths for developing renewable energy coupled with hydrogen energy, abandonment of wind/light for hydrogen production from electrolyzed water and wind power/photovoltaic off-grid hydrogen production are the most economical and promising hydrogen production technologies. Hydrogen produced by renewable energy can generate electricity from fuel cells to promote renewable energy consumption and grid connection and be supplied to nearby hydrogen refueling stations. When hydrogen is inconvenient to transport, it can be converted into methanol nearby or transported with natural gas mixed with hydrogen. For comprehensive energy service parks, electrolysis hydrogen production technology can not only incre ase the consumption of wind power and photovoltaics in the park but also realize the interconnection of multiple types of energy networks such as power grids and heating networks, gas networks, and transportation networks through fuel cells or gas turbines. In the future, integrated energy services The application prospects in the park are very broad.

\section{CONFLICT OF INTEREST}

There is no conflict of interests.

\section{REFERENCES}

1. Moriarty, P. and Honnery, D. 2007. "Intermittent renewable energy: The only future source of hydrogen?" International Journal of Hydrogen Energy, 32(12), pp.1616-1624. https://doi.org/10.1016/j.ijhydene.2006.12.008

2. Aghahosseini, A., Bogdanov, D., Barbosa, L. S. N. S. and Breyer, C. 2019. "Analysing the feasibility of powering the Americas with renewable energy and inter-regional grid interconnections by 2030." Renewable and Sustainable Energy Reviews, 105, pp.187-

\section{5. https://doi.org/10.1016/j.rser.2019.01.046}

3. da Silva Veras, T., Mozer, T. S., da Costa Rubim Messeder dos Santos, D. and da Silva César, A. 2017. "Hydrogen: Trends, production and characterization of the main process worldwide." International Journal of Hydrogen Energy, 42(4), pp.2018-2033. https://doi.org/10.1016/j.ijhydene.2016.08.219

4. Xianxu, H., Jing, W., Ling, J. and Qingshan, X.2016. "Review on key technologies and applications of hydrogen energy storage system." Energy Storage Science and Technology, 5(2), pp.197203. https://doi.org/10.3969/j.issn.2095-4239.2016.02.011

5. Du, J. and Ouyang, D. 2017. "Progress of Chinese electric vehicles industrialization in 2015: A review." Applied Energy, 188, pp.529-546. https://doi.org/10.1016/j.apenergy.2016.11.129

6. Staffell, I., Scamman, D., Velazquez Abad, A., Balcombe, P., Dodds, P. E., Ekins, P., Shah, N. and Ward, K. R. 2019. "The role of hydrogen and fuel cells in the global energy system." Energy \& Environmental Science, 12(2), pp.463-491. https://doi.org/10.1039/C8EE01157E

7. Li, Z., Zhang, W., Zhang, R. and Sun, H. 2020. "Development of renewable energy multi-energy complementary hydrogen energy system (A Case Study in China): A review.” Energy Exploration \& Exploitation, 38(6), pp.2099-2127. https://doi.org/10.1177/0144598720953512

8. Bakenne, A., Nuttall, W. and Kazantzis, N. 2016. "SankeyDiagram-based insights into the hydrogen economy of today." International Journal of Hydrogen Energy, 41(19), pp.7744 7753. https://doi.org/10.1016/j.ijhydene.2015.12.216

9. Lu, C., Zhang, R., Yang, G., Huang, H., Cheng, J. and Xu, S. 2021. "Study and performance test of $10 \mathrm{~kW}$ molten carbonate fuel cell power generation system." International Journal of Coal Science \& Technology, 8(3), pp.368-376. https://doi.org/10.1007/s40789021-00442-4

10. Chen, S. H., Zhang, K., Chang, L. P. and Wang, H. 2019. "Overview of traditional and newhydrogen production methods." Natural Gas Chemical Industry, 44(2), pp.122-127. Retrieved from

https://linkinghub.elsevier.com/retrieve/pii/S136403211731242X

11. Gesheng, H. U. A. N. G. and LIJinshan, W. 2019. "Status and economic analysis of hydrogen production technology from fossil raw materials." Chemical Industry and Engineering Progress, 38(12), pp.5217-5224

12. Caglayan, D. G., Weber, N., Heinrichs, H. U., Linßen, J., Robinius, M., Kukla, P. A. and Stolten, D. 2020. "Technical potential of salt caverns for hydrogen storage in Europe." International Journal of Hydrogen Energy, 45(11), pp.67936805. https://doi.org/10.1016/j.ijhydene.2019.12.161

13. Yu, H. and Yi, B. 2018. "Hydrogen for Energy Storage and Hydrogen Production from Electrolysis." Chinese Journal of Engineering Science, 20(3), pp.58-65.https://doi.org/10.15302/JSSCAE-2018.03.009

14. Rezaei, M., Salimi, M., Momeni, M. and Mostafaeipour, A. 2018. "Investigation of the socio-economic feasibility of inst alling wind turbines to produce hydrogen: Case study." International Joumal of Hydrogen Energy, 43(52), pp.23135-23147. https://doi.org/10.1016/j.ijhydene.2018.10.184

15. Buttler, A. and Spliethoff, H. 2018. "Current status of water electrolysis for energy storage, grid balancing and sector coupling via power-to-gas and power-to-liquids: A review." Renewable and Sustainable Energy Reviews, 82, pp.2440-2454. https://doi.org/10.1016/j.rser.2017.09.003

16. Götz, M., Lefebvre, J., Mörs, F., McDaniel Koch, A., Graf, F., Bajohr, S., Reimert, R. and Kolb, T. 2016. "Renewable Power-toGas: A technological and economic review." Renewable Energy, 85, pp.1371-1390. https://doi.org/10.1016/j.renene.2015.07.066

17. Zhang, N., Chen, H., Ma, X., Shen, S. and Wang, G. 2019. "Research Progress of High Density Solid-st ate Hydrogen Storage 
Materials." Manned Spaceflight, 25, pp.116-121.

18. Abe, J. O., Popoola, A. P. I., Ajenifuja, E. and Popoola, O. M. 2019. "Hydrogen energy, economy and storage: Review and recommendation." International Journal of Hydrogen Energy, 44(29), https://doi.org/10.1016/j.ijhydene.2019.04.068 pp.15072-15086

19. Liu, H., Xu, L., Liu, S., Sheng, P., Zhao, G., Wang, B., Li, H., Ma, G., Han, Y., Chen, X. and Wang, X. 2017. 'Technical indicators for solid-state hydrogen storage systems and hydrogen storage materials for grid-scale hydrogen energy storage application." Power System Technology, 4(10), pp.3376-3384. Retrieved from https://linkinghub.elsevier.com/retrieve/pii/S0360319919347299

20. Moradi, R. and Groth, K. M. 2019. "Hydrogen storage and delivery: Review of the state of the art technologies and risk and reliability analysis." International Journal of Hydrogen Energy, 44(23), https://doi.org/10.1016/j.ijhydene.2019.03.041 pp.12254-12269.

21. Sun, M.-B., Wang, Z.-G., Liang, J.-H. and Geng, H. 2008. "Flame Characteristics in Supersonic Combust or with Hydrogen Injection Upstream of Cavity Flameholder." Journal of Propulsion and Power, 24(4), pp.688-696. https://doi.org/10.2514/1.34970

22. Bailera, M., Lisbona, P., Romeo, L. M. and Espatolero, S. 2017. "Power to Gas projects review: Lab, pilot and demo plants for storing renewable energy and CO2." Renewable and Sustainable Energy Reviews, 69, pp.292-312 https://doi.org/10.1016/j.rser.2016.11.130

23. Noussan, M., Raimondi, P. P., Scita, R. and Hafner, M. 2020. “The Role of Green and Blue Hydrogen in the Energy Transition-A Technological and Geopolitical Perspective." Sustainability, 13(1), pp.298. https://doi.org/10.3390/su13010298

24. Ishaq, H., Dincer, I. and Naterer, G. F. 2018. "Performance investigation of an integrated wind energy system for cogeneration of power and hydrogen." International Journal of Hydrogen Energy, 43(19), pp.9153-9164. https://doi.org/10.1016/j.ijhydene.2018.03.139

25. McKenna, R. C., Bchini, Q., Weinand, J. M., Michaelis, J., König S., Köppel, W. and Fichtner, W. 2018. "The fut ure role of Powerto-Gas in the energy transition: Regional and local technoeconomic analyses in Baden-Württemberg." Applied Energy, 212, pp.386-400. https://doi.org/10.1016/j.apenergy.2017.12.017

26. Ghaib, K. and Ben-Fares, F.-Z. 2018. "Power-to-Methane: A state-of-the-art review." Renewable and Sustainable Energy Reviews, 81, pp.433-446. https://doi.org/10.1016/j.rser.2017.08.004

27. Li, J. R., Lin, J., Xiao, J. Y., Song, Y. and Teng, Y. 2020. "T echnical and energy consumption comparison of power-tochemicals (P2X) technologies for renewable energy integration." Journal of Global Energy Interconnection, 3(01), pp.86-96.

28. Li, Z., Guo, P., Han, R. and Sun, H. 2019. "Current status and development trend of wind power generation-based hydrogen production technology." Energy Exploration \& Exploitation, 37(1), pp.5-25. https://doi.org/10.1177/0144598718787294

29. Zhigang, S. and Baolian, Y. 2019. “Developing Trend and Present Stat us of Hydrogen Energy and Fuel Cell Development." Bulletin of Chinese Academy of Sciences, 34(04), pp.469-477.

30. Iris, Ç. and Lam, J. S. L. 2019. “A review of energy efficiency in ports: Operational strategies, technologies and energy management systems." Renewable and Sustainable Energy Reviews, 112 , https://doi.org/10.1016/j.rser.2019.04.069

pp.170-182.

31. Javed, M. S., Ma, T., Jurasz, J. and Amin, M. Y. 2020. "Solar and wind power generation systems with pumped hydro storage: Review and future perspectives." Renewable Energy, 148, pp.176-192. https://doi.org/10.1016/j.renene.2019.11.157

32. Greiner, C., Korpas, M. and Holen, A. 2007. "A Norwegian case study on the production of hydrogen from wind power."
International Journal of Hydrogen Energy, 32(10-11), pp.15001507. https://doi.org/10.1016/j.ijhydene.2006.10.030

33. Zivar, D., Kumar, S. and Foroozesh, J. 2021. "Underground hydrogen storage: A comprehensive review." International Journal of Hydrogen Energy, 46(45), pp.23436-23462. https://doi.org/10.1016/j.ijhydene.2020.08.138

34. Zhang, G. and Wan, X. 2014. "A wind-hydrogen energy storage system model for massive wind energy curtailment." International Journal of Hydrogen Energy, 39(3), pp.1243-1252. https://doi.org/10.1016/j.ijhydene.2013.11.003

35. Hou, P., Enevoldsen, P., Eichman, J., Hu, W., Jacobson, M. Z. and Chen, Z. 2017. "Optimizing investments in coupled offshore wind -electrolytic hydrogen storage systems in Denmark." Joumal of Power Sources, 359, pp.186-197. https://doi.org/10.1016/j.jpowsour.2017.05.048

36. Weidong, G. and Zhuoyong, Y. 2012. "Research on non-gridconnected wind power/water-electrolytic hydrogen production system." International Journal of Hydrogen Energy, 37(1), pp.737-740. https://doi.org/10.1016/j.ijhydene.2011.04.109

37. De Luna, P., Hahn, C., Higgins, D., Jaffer, S. A., Jaramillo, T.F. and Sargent, E. H. 2019. "What would it take for renewably powered electrosynthesis to displace petrochemical processes?" Science, 364(6438), $\quad$ pp.eaav3506. https://doi.org/10.1126/science.aav3506

38. Zhou, J. Z. 2021. "Role of mineral flotation technology in improving bitumen extraction from minedthabasca oil sands. Next generation of water-based oil sands extraction." The Canadian Journal of Chemical Engineering, 99(3), pp.755-777. https://doi.org/10.1002/cjce.23874

39. Chen, C., Lu, Y. and Banares-Alcantara, R. 2019. "Direct and indirect electrification of chemical industry using methanol production as a case study." Applied Energy, 243, pp.71-90. https://doi.org/10.1016/j.apenergy.2019.03.184

40. Huang, M., Yong, W. U. and Xizhi, W. E. N. 2013. "Feasibility analysis of hydrogen transport in natural gas pipeline." Gas \& Heat, 33(4), pp.39-42.

41. Xiangyang, M. A., Xiaomei, H. U. A. N. G. and Chang, W. U. 2018. "Study on the influence of natural gas hydrogenation on combustion characteristics of domestic gas cooker." Renewable Energy Resources, 36(12), pp.1746-1751.

42. Aghahosseini, A., Bogdanov, D. and Breyer, C. 2020. "Towards sustainable development in the MENA region: Analysing the feasibility of a $100 \%$ renewable electricity system in $2030 . "$ Energy Strategy Reviews, 28, pp.100466. https://doi.org/10.1016/j.esr.2020.100466

43. Eppinger, J. and Huang, K.-W. 2017. "Formic Acid as a Hydrogen Energy Carrier." ACS Energy Letters, 2(1), pp.188-195. https://doi.org/10.1021/acsenergylett.6b00574

44. McDowall, W. 2012. "Technology roadmaps for transition management: The case of hydrogen energy." Technological Forecasting and Social Change, 79(3), pp.530-542. https://doi.org/10.1016/j.techfore.2011.10.002

45. Solomon, B. D. and Banerjee, A. 2006. "A global survey of hydrogen energy research, development and policy." Energy $\begin{array}{lll}\text { Policy, 34(7), } & \text { pp.781-792. }\end{array}$ https://doi.org/10.1016/j.enpol.2004.08.007

46. Winter, C. 2005. "Into the hydrogen energy economy?milestones." International Journal of Hydrogen Energy, 30(7), pp.681-685. https://doi.org/10.1016/j.ijhydene.2004.12.011

47. Hijikata, T. 2002. "Research and development of international clean energy network using hydrogen energy (WE-NET)." International Journal of Hydrogen Energy, 27(2), pp.115-129. https://doi.org/10.1016/S0360-3199(01)00089-1

48. Marchenko, O. V. and Solomin, S. V. 2015. "The future energy: Hydrogen versus electricity." International Journal of Hydrogen 
Energy,

40(10), https://doi.org/10.1016/j.ijhydene.2015.01.132

49. Midilli, A., Ay, M., Dincer, I. and Rosen, M. A. 2005. "On hydrogen and hydrogen energy strategies." Renewable and Sustainable Energy Reviews, 9(3), pp.255-271. https://doi.org/10.1016/j.rser.2004.05.003

50. Barreto, L., Makihira, A. and Riahi, K. 2003. "The hydrogen economy in the 21 st century: a sust ainable development scenario.' International Journal of Hydrogen Energy, 28(3), pp.267-284. https://doi.org/10.1016/S0360-3199(02)00074-5

51. Zhang, F., Zhao, P., Niu, M. and Maddy, J. 2016. "The survey of key technologies in hydrogen energy storage." International Journal of Hydrogen Energy, 41(33), pp.14535-14552. https://doi.org/10.1016/j.ijhydene.2016.05.293

52. Momirlan, M. and Veziroglu, T. . 2002. "Current status of hydrogen energy." Renewable and Sustainable Energy Reviews, 6(1-2), pp.141-179. https://doi.org/10.1016/S13640321(02)00004-7

53. Midilli, A. and Dincer, I. 2007. "Key strategies of hydrogen energy systems for sustainability." International Journal of Hydrogen Energy, 32(5), pp.511-524. https://doi.org/10.1016/j.ijhydene.2006.06.050

54. Veziroglu, T. N. (n.d.). "21st Century's Energy: Hydrogen Energy System." In Assessment of Hydrogen Energy for Sustainable Development (pp. 9-31). Dordrecht: Springer Netherlands. https://doi.org/10.1007/978-1-4020-6442-5_2

55. Winter, C.-J. 2009. "Hydrogen energy - Abundant, efficient, clean: A debate over the energy-system-of-changes.". International Journal of Hydrogen Energy, 34(14), pp.S1-S52. https://doi.org/10.1016/j.ijhydene.2009.05.063

56. Elam, C. 2003. "Realizing the hydrogen future: the International Energy Agency's efforts to advance hydrogen energy technologies." International Journal of Hydrogen Energy, 28(6), pp.601-607.https://doi.org/10.1016/S0360-3199(02)00147-7

57. Cipriani, G., Di Dio, V., Genduso, F., La Cascia, D., Liga, R. Miceli, R. and Ricco Galluzzo, G. 2014. "Perspective on hydrogen energy carrier and its automotive applications." International Journal of Hydrogen Energy, 39(16), pp.8482-8494. https://doi.org/10.1016/j.ijhydene.2014.03.174

58. Dincer, I. 2002. "Technical, environmental and exergetic aspects of hydrogen energy syst ems." International Journal of Hydrogen Energy, 27(3), pp.265-285. https://doi.org/10.1016/S03603199(01)00119-7

59. Ulleberg, Ø., Nakken, T. and Eté, A. 2010. "The wind/hydrogen demonstration system at Utsira in Norway: Evaluation of system performance using operational data and updat ed hydrogen energy system modeling tools." International Journal of Hydrogen Energy, 35(5), https://doi.org/10.1016/j.ijhydene.2009.10.077

60. Turner, J. A. 2004. "Sustainable Hydrogen Production." Science, 305(5686), pp.972-974. https://doi.org/10.1126/science.1103197

61. Armaroli, N. and Balzani, V. 2011. "The Hydrogen Issue." ChemSusChem, 4(1), pp.21-36. https://doi.org/10.1002/cssc.201000182

62. Ball, M. and Wietschel, M. 2009. "The future of hydrogen opportunities and challenges." International Journal of Hydrogen Energy, 34(2), pp.615-627. https://doi.org/10.1016/j.ijhydene.2008.11.014

63. Züttel, A. 2003. "Materials for hydrogen storage." Materials Today, 6(9), pp.24-33. https://doi.org/10.1016/S13697021(03)00922-2

64. Holladay, J. D., Hu, J., King, D. L. and Wang, Y. 2009. “An overview of hydrogen production technologies." Catalysis Today, 139(4), pp.244-260. https://doi.org/10.1016/j.cattod.2008.08.039

65. Alefeld, G. and Völkl, J. 1978. Hydrogen in metals I-Basic properties. Berlin and New York, Springer-Verlag (Topics in Applied Physics. Volume 28).

66. Chen, P., Xiong, Z., Luo, J., Lin, J. and Tan, K. L. 2002 "Int eraction of hydrogen with metal nitrides and imides." Nature, 420(6913), pp.302-304. https://doi.org/10.1038/nature01210

67. Ramachandran, R. 1998. "An overview of industrial uses of hydrogen." International Journal of Hydrogen Energy, 23(7), pp.593-598.https://doi.org/10.1016/S0360-3199(97)00112-2

68. Jeffrey, G. A. and Saenger, W. 2012. Hydrogen bonding in biological structures. Springer Science \& Business Media.

69. Pimentel, G. C. and McClellan, A. L. 1971. "Hydrogen Bonding" Annual Review of Physical Chemistry, 22(1), pp.347-385. https://doi.org/10.1146/annurev.pc.22.100171.002023

70. Neill, S. 2002. "Hydrogen peroxide signalling." Current Opinion in Plant Biology, 5(5), pp.388-395. https://doi.org/10.1016/S1369-5266(02)00282-0

71. Roland, U., Braunschweig, T. and Roessner, F. 1997. "On the nat ure of spilt-over hydrogen.” Journal of Molecular Catalysis A Chemical, 127(1-3), pp.61-84. https://doi.org/10.1016/S13811169(97)00110-6

72. Scheiner, S. 1997. Hydrogen bonding: a theoretical perspective. Oxford University Press on Demand.

73. Keston, A. S. and Brandt, R. 1965. "The fluorometric analysis of ultramicro quantities of hydrogen peroxide." Analytical Biochemistry, 11(1), pp.1-5. https://doi.org/10.1016/00032697(65)90034-5

74. Hvidt, A. and Nielsen, S. O. 1966. "Hydrogen Exchange in Proteins." Advances in Protein Chemistry, 21, pp.287-386. https://doi.org/10.1016/S0065-3233(08)60129-1

75. Brown, I. D. 1976. "On the geometry of O-H...O hydrogen bonds." Acta Crystallographica Section A, 32(1), pp.24-31. https://doi.org/10.1107/S0567739476000041

76. Jain, I. P. 2009. "Hydrogen the fuel for 21 st century." International Journal of Hydrogen Energy, 34(17), pp.73687378. https://doi.org/10.1016/j.ijhydene.2009.05.093

77. McDonald, I. K. and Thornton, J. M. 1994. "Satisfying Hydrogen Bonding Potential in Proteins." Journal of Molecular Biology, 238(5), pp.777-793. https://doi.org/10.1006/jmbi.1994.1334

78. Weaver, P. F., Lien, S. and Seibert, M. 1980. "Photobiological production of hydrogen." Solar Energy, 24(1), pp.3-45. https://doi.org/10.1016/0038-092X(80)90018-3

79. Chen, B., Ivanov, I., Klein, M. L. and Parrinello, M. 2003 "Hydrogen Bonding in Water." Physical Review Letters, 91(21), pp.215503. https://doi.org/10.1103/PhysRevLett.91.215503

80. Ewan, B. and Allen, R. 2005. "A figure of merit assessment of the rout es to hydrogen." International Journal of Hydrogen Energy, $30(8)$, https://doi.org/10.1016/j.ijhydene.2005.02.003 pp.809-819.

81. Brewer, G. D. 2017. Hydrogen aircraft technology. Routledge.

82. Hübert, T., Boon-Brett, L., Black, G. and Banach, U. 2011. "Hydrogen sensors - A review." Sensors and Actuators B: Chemical, 157(2), pp.329-352. https://doi.org/10.1016/j.snb.2011.04.070

83. Dincer, I. and Acar, C. 2015. "Review and evaluation of hydrogen production methods for better sustainability." International Journal of Hydrogen Energy, 40(34), pp.11094-11111. https://doi.org/10.1016/j.ijhydene.2014.12.035

84. Abbas, H. F. and Wan Daud, W. M. A. 2010. "Hydrogen production by methane decomposition: A review." International Journal of Hydrogen Energy, 35(3), pp.1160-1190. https://doi.org/10.1016/j.ijhydene.2009.11.036

85. Sakintuna, B., Lamaridarkrim, F. and Hirscher, M. 2007. "Metal hydride materials for solid hydrogen storage: A review International Journal of Hydrogen Energy, 32(9), pp.1121-1140. 
https://doi.org/10.1016/j.ijhydene.2006.11.022

86. Steinfeld, A. 2005. "Solar thermochemical production of hydrogen-a review." Solar Energy, 78(5), pp.603-615. https://doi.org/10.1016/j.solener.2003.12.012

87. Minggu, L. J., Wan Daud, W. R. and Kassim, M. B. 2010. “An overview of photocells and photoreactors for photoelectrochemical water splitting." International Journal of Hydrogen Energy, 35(11), pp.5233-5244. https://doi.org/10.1016/j.jhydene.2010.02.133

88. Azeez, S., Garba, U. and Danshehu, B. 2020. “Application of Aspen HYSYS for Predicting the Effects of Impurities on Thermodynamic Performance of Glycerol Autothermal Reforming for Hydrogen Production." Iranian (Iranica) Joumal of Energy and Environment, 11(1), pp.51-56. https://doi.org/10.5829/IJEE.2020.11.01.08

89. Rahman-Al Ezzi, A. and Alhamdiny, S. 2019. "Elimination of Chloroform $(\mathrm{CHCl} 3)$ from Drinking Water via a Synergistic Effect of Stripping, Oxidation and Adsorption Process in Air Lift Loop Reactor." Iranian (Iranica) Journal of Energy and Environment, 10(2), pp.85-90. https://doi.org/10.5829/IJEE.2019.10.02.03

90. Akkoli, K., Goudadi, S., Shivashimpi, M. and Topannavar, S.
2020. "Biomass Characterization and Gasifier Design for Agricultural Residues." Iranian (Iranica) Journal of Energy and Environment, 11(3), pp.198-203. https://doi.org/10.5829/IJEE.2020.11.03.04

91. Raghavendra, N. 2018. "Corrosion Studies of Carbon Steel in 3\% $\mathrm{NaCl}$ Solution in Presence of Expired Ceftin: Investigation of Environmental Friendly Corrosion Inhibitor." Iranian (Iranica) Journal of Energy and Environment, 9(4), pp.295-298. https://doi.org/10.5829/IJEE.2018.09.04.10

92. Guidotti, T. L. 1996. "Hydrogen Sulphide." Occupational Medicine, 46(5), pp.367-371. https://doi.org/10.1093/occmed/46.5.367

93. Chi, J. and Yu, H. 2018. "Water electrolysis based on renewable energy for hydrogen production." Chinese Journal of Catalysis, 39(3), pp.390-394. https://doi.org/10.1016/S18722067(17)62949-8

94. Alshehri, A., Mogi, G. and Endo, R. 2018. "Spatial Data-Based Techno-economic Evaluation of Solar Hydrogen Production in the Middle East and North Africa (MENA) Region.” In 2018 IEEE Innovative Smart Grid Technologies - Asia (ISGT Asia) (pp. 115120). IEEE. https://doi.org/10.1109/ISGT -Asia.2018.8467781

\section{COPYRIGHTS}

(C2021 The author(s). This is an open access article distributed under the terms of the Creative Commons Attribution (CC BY 4.0), which permits unrestricted use, distribution, and reproduction in any medium, as long as the original authors and source are cited. No permission is required from the authors or the publishers.

انرزى هيدروزن داراى مزاياى كربن كم و تميزى، جِالى انرزى بالا و بازده تبديل بالا است و انتظار مىرود نقشى محورى در انتقال انرزى جين داشته باشد.

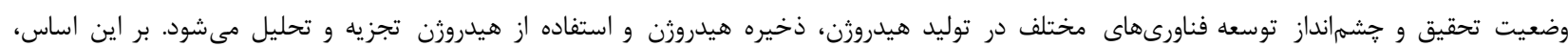

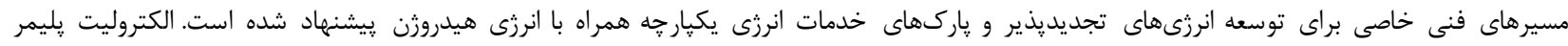

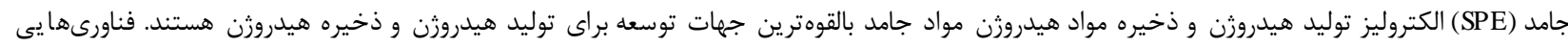

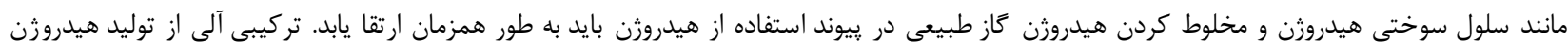

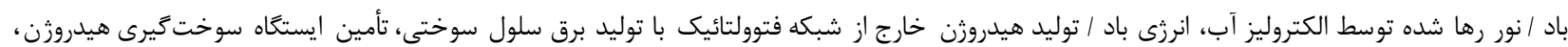

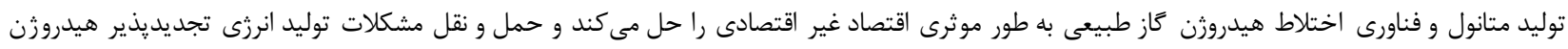

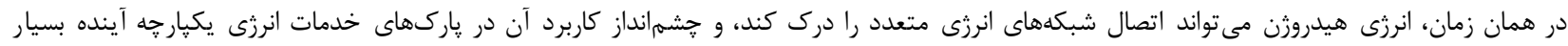
كسترده است. 